\title{
Influence of Seed Size and Pre-Sowing Treatments on Germination Parameters of Sapindus mukorossi Gaertn under Laboratory Condition
}

\author{
Varun Attri*, K.S. Pant, Navjot Singh and Vipasha Negi
}

Department of Silviculture and Agroforestry, University of Horticulture and Forestry,

Nauni, Solan, H.P., India

*Corresponding author

\section{A B S T R A C T}

The seeds of Sapindus mukorossi were collected from trees with the ideal phenotypical characters of good height, large crown and medium aged with abundant seed production. The fresh seeds were collected manually and the extracted seeds were cleaned and thoroughly hand mixed to improve the homogeneity during the sampling. The seeds based on their diameter were graded into three classes i.e. small $\left(\mathrm{L}_{1}\right)(<1.2 \mathrm{~cm})$, medium $\left(\mathrm{L}_{2}\right)$ $(1.2-1.4 \mathrm{~cm})$ and large $\left(\mathrm{L}_{3}\right)(>1.4 \mathrm{~cm})$. The graded seeds were subjected to five different pre-sowing treatments for germination viz., Control $\left(\mathrm{T}_{1}\right)$ (untreated seeds), Cold water treatment for 72 hours $\left(\mathrm{T}_{2}\right)$, Cow dung treatment for 7 days $\left(\mathrm{T}_{3}\right)$, Concentrated $\mathrm{H}_{2} \mathrm{SO}_{4}$ for 20 minutes followed by rinsing under running tap water $\left(\mathrm{T}_{4}\right)$ and Hot water treatment $\left(80^{\circ} \mathrm{C}\right)$ followed by 24 hours soaking $\left(\mathrm{T}_{5}\right)$. The graded and treated seeds were kept in seed germinator for four week. Watering and spray of fungicide was carried out manually when

\section{Keywords}

Seed size, Presowing treatments, Germination, Laboratory condition.

\section{Article Info}

Accepted: xx August 2017 Available Online: xx October 2017 necessary. The effects of seed size and pre-sowing treatments on germination of seeds were explored periodically through counting the germinated seeds. The study revealed that seed parameters of the Sapindus mukorossi were significantly influenced by seed size categories. The weight of 100 seeds was recorded maximum $(210.23 \mathrm{~g})$ in large size $\left(\mathrm{L}_{3}\right)$ seed category which is significantly differed from $\mathrm{L}_{2}$ (medium) and $\mathrm{L}_{1}$ (small). However no significant difference has been observed among seed viability. The highest germination per cent $(68.52 \%)$, germination capacity (74.07) and germination energy (41.48\%) was recorded in concentrated $\mathrm{H}_{2} \mathrm{SO}_{4}$ for 20 minutes followed by rinsing under running tap water $\left(\mathrm{T}_{4}\right)$ pre-sowing treatment while the lowest germination per cent $(56.66 \%)$, germination capacity $(64.07 \%)$ and germination energy minimum $(30.74 \%)$ in $\mathrm{T}_{1}$ (control). All treatments were significantly different from each other. On the other hand, among three seed category, large seed category $\left(\mathrm{L}_{3}\right)$ was recorded maximum per cent germination (76.22\%), germination capacity $(83.55 \%)$ and germination energy $(47.77 \%)$ while the minimum germination per cent $(46.22 \%)$ germination capacity $(54.44 \%)$ and germination energy $(25.33 \%)$ was found in small seed category $\left(\mathrm{L}_{1}\right)$. But all three seed size categories differed significantly from each other. Among the treatment combinations, germinability parameters were recorded maximum in $\mathrm{T}_{4} \mathrm{~L}_{3}$ (concentrated $\mathrm{H}_{2} \mathrm{SO}_{4}$ for 20 minutes followed by rinsing under running tap water+ large seed category). The seed size and pre sowing treatments often controls the germination and initial seedling growth in many tree species. Pre-sowing treatment methods are employed for overcoming seed dormancy and are used not only to ensure the rapid germination but it also decreases labour, cost and time for nursery production. 


\section{Introduction}

Forest ecosystem plays an important role in the livelihood of people living in both mountains and lowland areas by supplying fresh water and air as well as providing a diversity of valuable forest products for medicine and food. Sapindus mukorossi or soapnut tree (Ritha) is an important MPTs of north India, belongs to family Sapindaceae. The tree is native to China and Japan and much more cultivated in North India, in the moister tracts along the foot of Himalayas from Ravi eastwards upto 1500 m elevation. The tree is also found wild in the valleys of north-western Himalayas, Assam and West Bengal. It is also planted in avenues. In Nagaland, it is cultivated extensively for small scale industries (Troup, 1921). The tree is cultivated in many parts of India as ornamental and for its saponaceous fruits.

Sapindus mukorossi is a moderate sized deciduous tree. It has a spreading crown and short clean bole attaining a height of about 20 $\mathrm{m}$. The trees are leafless from December/January to March/April. The new leaves appear with panicles of flower during May-June.

The flowers are small and greenish white, polygamous and mostly bisexual in panicles at the end of the branches. The fruits appear in July-August and ripen by NovemberDecember. These are solitary, round nuts 2$2.5 \mathrm{~cm}$ diameters, fleshy, yellowish brown in colour. Seeds are $0.8-1.3 \mathrm{~cm}$ in diameter, enclosed in a black, smooth and hard globose covering. The fruits are collected from the trees during winter months for seeds and or sale in the market as soap nut. The seeds retain their viability for one to two years. Occasionally, the tree come up from the selfsown seeds and can also be raised artificially by direct sowings or by transplanting the nursery raised seedlings.
The dried fruits of 'Ritha' are most valuable part of the plant. Its fleshy portion contain saponin, which is a good substitute for washing soap and as such is used for the preparation of quality shampoos, detergents (Bahar and Singh, 2007). Soap nuts have medicinal value as an expectorant, emetic, contraceptive and for treatment of excessive salivation, epilepsy, psoriasis, head lice and migraines. Soap nut inhibit tumor cell growth. Soap nut are among the list of herbs and minerals in Ayurveda. Nuts are used in ayurvedic medicine for the treatment of eczema and psoriasis.

Among various factors responsible for successful plantation programme, use of quality seeds in terms of genetic and physical attributes is of paramount importance. The seed size have been found to have a marked bearing on the quality of the nursery stock in numerous species and Sapindus mukorossi need not necessarily provide an exception to this. It is therefore, worthwhile to determine the optimum seed size for improving the physical quality of the seedlings.

In Sapindus mukorossi, the seeds have mechanical dormancy caused by hard seed coat (Troup, 1921). Pre-sowing treatment methods are employed for overcoming seed dormancy in many species. Pre-treatment methods have to be adjusted for individual species and seed lots depending upon experiment, knowledge, practices and experience (Schmidt, 2000). Knowledge of biology and physiology of a seed helps in identifying the nature of specific seed problems and probable pre-treatment method for breaking seed dormancy (Bhardwaj and Chakraborty, 1994). Physical dormancy differs between species, stage of maturity and degree of drought; pretreatment must be adjusted consequently. Physical dormancy may be overcome by manual scarification of the seed coat by piercing, nicking, chipping, 
filing or burning with the help of knife, needle, hot wire burner, abrasion paper (Catalan and Macchiavelli, 1991), Hot water treatment or acid treatment (Kobmoo and Hellum, 1984; Khasa, 1992). Seed treatments are applied to ensure faster and uniform germination rates.

Sapindus mukorossi importance lies in the sale of fruits, which are mainly sold in the local market. A number of farmers are earning livelihood by marketing and selling the fruits from their planted trees. As the domestication and cultivation started the demand for quality seedling during planting time is very high. But low, delayed and uneven germination has created problem in raising seedling in nursery. Therefore, the present study has been designed to explore the enhanced seed germination as well as growth performance of Sapindus mukorossi under different easily applicable pre-sowing treatments.

\section{Materials and Methods}

The present investigation was conducted in the laboratory of the Department of Silviculture and Agroforestry, Dr. Y.S. Parmar University of Horticulture and Forestry, Nauni, Solan, Himachal Pradesh. The seeds of Sapindus mukorossi were collected from trees with the ideal phenotypical characters of good height, large crown, and medium aged with abundant seed production. The seeds were collected from the three districts of Himachal Pradesh viz., Sirmour, Solan and Kullu. The fresh seeds were collected manually and packed in gunny bags and brought to laboratory. The extracted seeds were cleaned and thoroughly hand mixed to improve the homogeneity during the sampling. The seeds based on their diameter were graded into three classes i.e. small $\left(\mathrm{L}_{1}\right)$ $(<1.2 \mathrm{~cm})$, medium $\left(\mathrm{L}_{2}\right)(1.2-1.4 \mathrm{~cm})$ and large $\left(\mathrm{L}_{3}\right)(>1.4 \mathrm{~cm})$ (Fig. 1).
The graded seeds were subjected to five different pre-sowing treatments for germination viz., Control $\left(\mathrm{T}_{1}\right)$ (untreated seeds), Cold water treatment for 72 hours $\left(\mathrm{T}_{2}\right)$, Cow dung treatment for 7 days $\left(\mathrm{T}_{3}\right)$, Concentrated $\mathrm{H}_{2} \mathrm{SO}_{4}$ for 20 minutes followed by rinsing under running tap water $\left(\mathrm{T}_{4}\right)$ and Hot water treatment $\left(80^{\circ} \mathrm{C}\right)$ followed by 24 hours soaking $\left(\mathrm{T}_{5}\right)$.

The seeds were kept in germination trays under seed germinator for four week. Watering and spray of fungicide was carried out manually when necessary. The effects of seed size and pre-sowing treatments on germination of seeds were explored periodically through counting the germinated seeds. The following seed and germination parameters were recorded in laboratory condition.

\section{0 seed weight $(g)$}

One hundred freshly harvested and graded seeds were randomly selected in three replications and weighed. The mean of these weights was taken to get average weight of a 100 seeds as per ISTA method (ISTA, 1966).

\section{Seed viability $(\%)$}

Seed viability was determined by using Tetrazolium staining test (Bonner, 1974), which indicate the presence of live tissue. One per cent solution of TTC $(2,3,5$ Triphenyl Tetrazolium Chloride) is applied to fully imbibed seeds, which was cut and opened lengthwise without damaging the embryo. The seeds were left over night for 18 to $24 \mathrm{hrs}$ in the dark at $30^{\circ} \mathrm{C}$.

The live embryo, cotyledons and other tissue stained red indicated that the seeds are viable and unstained embryo is non-viable. The seeds were thereafter evaluated as viable and non- viable in percentage. 
Number of viable seeds

Seed viability $(\%)=$

Total number of seeds

\section{Germination per cent (GP)}

Germination per cent was calculated as the total number of seeds germinated at the end of experiment out of the total seeds sown in each treatment.

Number of seeds germinated
Germination $(\%)=$------------------ $\times 100$

Total number of seeds sown

\section{Germination capacity (\%)}

The cumulative number of seeds that germinated during the 28 days of test period plus the number of viable seeds at the end of the test expressed in percentage.

\section{Germination energy (\%)}

Germinating energy (GE) was calculated on the basis of the percentage of the total number of seeds that had germinated when the germination reached its peak.

Number of seeds germinated upto time of peak germination

$$
\mathrm{GE}(\%)=\frac{}{\text { Total number of seed sown }}
$$

The experiment was arranged in a completely randomized design with three replications and 30 seeds per replicate.

Seed germination was recorded daily up to 28 days after kept under seed germinator.

The least significant difference at $5 \%$ level was used for testing the significant differences among treatments. Significance of difference between seed size categories and treatments was tested by ANOVA.

\section{Results and Discussion}

The results emerging from the investigation have been presented under following heads:

\section{Seed weight and seed viability}

Seed parameters of the Sapindus mukorossi seeds were significantly influenced by seed size categories. The weight of 100 seeds was recorded maximum $(210.23 \mathrm{~g})$ in large size $\left(\mathrm{L}_{3}\right)$ seed category which is significantly differed from $\mathrm{L}_{2}$ (medium) and $\mathrm{L}_{1}$ (small). The maximum seed viability $(90 \%)$ was recorded in $\mathrm{L}_{3}$ (large size) and minimum $(80 \%)$ in $\mathrm{L}_{1}$ (small size). However no significant difference has been observed among seed viability (Table 1).

\section{Germination per cent (G P)}

The mean maximum germination (68.52\%) was recorded in $\mathrm{T}_{4}$ (concentrated $\mathrm{H}_{2} \mathrm{SO}_{4}$ for 20 minutes followed by rinsing under running tap water) followed by $T_{3}$ (cow dung for 7 days) pre-sowing treatment while the minimum per cent germination was recorded in $\mathrm{T}_{1}$ (control) $(56.66 \%)$. All treatments were significantly different from each other. On the other hand, among three seed category, large seed category $\left(\mathrm{L}_{3}\right)$ was recorded mean maximum per cent germination (76.22\%) while the least germination per cent $(46.22 \%)$ was found in small seed category $\left(\mathrm{L}_{1}\right)$. But all three seed size categories differed significantly from each other. Among the treatment combinations, maximum germination $(81.11 \%)$ was recorded in $\mathrm{T}_{4} \mathrm{~L}_{3}$ and minimum germination (38.89\%) was recorded in $\mathrm{T}_{1} \mathrm{~L}_{1}$ (Table 2).

\section{Germination capacity (\%)}

Germination capacity also differs significantly due to seed size categories and pre-sowing treatments. Among different pre- 
sowing treatment, the mean germination capacity was maximum $(74.07 \%)$ in $T_{4}$ (concentrated $\mathrm{H}_{2} \mathrm{SO}_{4}$ for 20 minutes followed by rinsing under running tap water) followed by $\mathrm{T}_{3}$ (cow dung treatment for 7 days) while it was recorded minimum $(64.07 \%)$ in $T_{1}$ (control). Among three seed category, large sized seeds $\left(\mathrm{L}_{3}\right)$ gave maximum germination capacity $(83.55 \%)$ while minimum germination capacity $(54.44 \%)$ was observed in small seed category $\left(\mathrm{L}_{1}\right)$. Among various treatment combinations maximum germination capacity was recorded in $\mathrm{T}_{4} \mathrm{~L}_{3}$ $(88.89 \%)$ which was statistically at par with $\mathrm{T}_{3} \mathrm{~L}_{3} \quad(87.77 \%)$ whereas the lowest germination capacity was recorded in $\mathrm{T}_{1} \mathrm{~L}_{1}$ $(48.89 \%)$ treatment combination (Table 3).

\section{Germination energy $(\%)$}

Germination energy also differs significantly due to seeds size categories and pre-sowing treatments. The pre-sowing treatments $\mathrm{T}_{4}$ and $\mathrm{T}_{3}$ registered maximum germination energy with the value of $41.48 \%$ and $40.00 \%$, respectively, whereas, it was recorded minimum in $\mathrm{T}_{1}$ and $\mathrm{T}_{2}$ with a value of $30.74 \%$ and $32.22 \%$, respectively. On the other hand among various seed categories, $\mathrm{L}_{3}$ registered maximum germination energy with a value of $47.77 \%$ and it was recorded minimum in $\mathrm{L}_{1}$ seed category with a value of $25.33 \%$. Among different treatment combinations, $\mathrm{T}_{4} \mathrm{~L}_{3}$ performed best with highest germination energy (54.44\%) which was statistically at par with $\mathrm{T}_{3} \mathrm{~L}_{3}(52.22 \%)$ while $\mathrm{T}_{1} \mathrm{~L}_{1}$ and $\mathrm{T}_{2} \mathrm{~L}_{1}$ recorded the poorest germination energy with a value of $20.00 \%$ and $22.22 \%$, respectively (Table 4).

Seed weight varied significantly among different seed size categories, maximum seed weight was recorded in large seeds $\left(\mathrm{L}_{3}\right)$ and minimum in small seeds $\left(\mathrm{L}_{1}\right)$. This may be due to the reasons for the difference in the seed weight may be ascertained due to seed size variation. The seed size usually reflects the comparative nutrient pool and energy of a seed which affects the future growth and development. The bigger seed size and more seed weight contain more amount of reserve food material in contrast to smaller seed (Athaya, 1985). These results are in line with the findings of Gurunathan et al., (2009) for Jatropha curcas. Similar results have also been reported for Emblica officinalis, Syzygium cumini, Zizyphus mauritiana and Tamarindus indica (Parameswari and Srimathi, 2009) and Pongamia pinnata (Manonmani et al., 1996).

Seed viability found non-significant among different seed size categories though maximum seed viability was recorded in large seeds $\left(\mathrm{L}_{3}\right)$ and minimum in small seeds. Viability of seed is much affected by the stage of maturity reached at the time of its collection (Bonner, 1974), its moisture content and the temperature to which it is exposed (Mathur et al., 1984).

Table.1 Effect of seed size on 100 seed weight and viability of freshly collected seeds of Sapindus mukorossi

\begin{tabular}{|l|c|c|}
\hline \multicolumn{1}{|c|}{ Category } & 100 Seed Weight $(\mathbf{g})$ & Viability (\%) \\
\hline $\mathbf{L}_{\mathbf{1}}($ Small) & 121.30 & $80.00(8.94)$ \\
\hline $\mathbf{L}_{\mathbf{2}}($ Medium) & 162.83 & $87.78(9.37)$ \\
\hline $\mathbf{L}_{\mathbf{3}}$ (Large) & 210.23 & $90.00(9.49)$ \\
\hline \multicolumn{1}{|c|}{ CD $(\mathbf{0 . 0 5})$} & 3.4871 & $\mathrm{NS}$ \\
\hline
\end{tabular}

Note- Figures given in parenthesis are square root transformed values 
Table.2 Effect of seed size and pre-sowing treatments on germination (\%) of Sapindus mukorossi under laboratory condition

\begin{tabular}{|c|c|c|c|c|}
\hline $\begin{array}{l}\text { Category } \\
\text { Treatments }\end{array}$ & $\mathbf{L}_{1}$ & $\mathbf{L}_{2}$ & $\mathbf{L}_{3}$ & Mean \\
\hline $\mathbf{T}_{1}$ & $\begin{array}{c}38.89 \\
(38.56)\end{array}$ & $\begin{array}{c}58.89 \\
(50.10)\end{array}$ & $\begin{array}{c}72.22 \\
(58.18)\end{array}$ & $\begin{array}{c}56.66 \\
(48.95)\end{array}$ \\
\hline $\mathbf{T}_{2}$ & $\begin{array}{c}43.33 \\
(41.14)\end{array}$ & $\begin{array}{c}61.11 \\
(51.40)\end{array}$ & $\begin{array}{c}74.44 \\
(59.62)\end{array}$ & $\begin{array}{c}59.63 \\
(50.72)\end{array}$ \\
\hline$\overline{T_{3}}$ & $\begin{array}{c}50.00 \\
(44.98)\end{array}$ & $\begin{array}{c}67.77 \\
(55.40)\end{array}$ & $\begin{array}{c}77.77 \\
(61.86)\end{array}$ & $\begin{array}{c}65.18 \\
(54.08)\end{array}$ \\
\hline $\mathbf{T}_{4}$ & $\begin{array}{c}53.33 \\
(46.89)\end{array}$ & $\begin{array}{c}71.11 \\
(57.47)\end{array}$ & $\begin{array}{c}81.11 \\
(64.23)\end{array}$ & $\begin{array}{c}68.52 \\
(56.20)\end{array}$ \\
\hline $\mathbf{T}_{5}$ & $\begin{array}{c}45.55 \\
(42.43)\end{array}$ & $\begin{array}{c}65.55 \\
(54.04)\end{array}$ & $\begin{array}{c}75.55 \\
(60.35)\end{array}$ & $\begin{array}{c}62.22 \\
(52.27)\end{array}$ \\
\hline Mean & $\begin{array}{c}46.22 \\
(42.80)\end{array}$ & $\begin{array}{c}64.89 \\
(53.68) \\
\end{array}$ & $\begin{array}{c}76.22 \\
(60.85) \\
\end{array}$ & \\
\hline \multirow[t]{3}{*}{$\mathrm{CD}(0.05)$} & \multicolumn{2}{|c|}{ Treatment (T) } & \multicolumn{2}{|l|}{1.32} \\
\hline & \multicolumn{2}{|c|}{ Category (L) } & \multicolumn{2}{|l|}{1.02} \\
\hline & \multicolumn{2}{|l|}{$\mathrm{T} \times \mathrm{L}$} & \multicolumn{2}{|l|}{2.28} \\
\hline
\end{tabular}

Note-Figures in the parentheses are arc- sine transformed values

Table.3 Effect of seed size and pre-sowing treatments on germination capacity (\%) of Sapindus mukorossi under laboratory condition

\begin{tabular}{|c|c|c|c|c|}
\hline $\begin{array}{c}\text { Category } \\
\text { Treatments }\end{array}$ & $\mathbf{L}_{1}$ & $\mathbf{L}_{2}$ & $\mathbf{L}_{3}$ & MEAN \\
\hline $\mathrm{T}_{1}$ & $\begin{array}{c}48.89 \\
(44.36)\end{array}$ & $\begin{array}{c}65.55 \\
(54.07)\end{array}$ & $\begin{array}{c}77.77 \\
(61.89)\end{array}$ & $\begin{array}{c}64.07 \\
(53.44)\end{array}$ \\
\hline $\mathbf{T}_{2}$ & $\begin{array}{c}52.22 \\
(46.27)\end{array}$ & $\begin{array}{c}67.77 \\
(55.42)\end{array}$ & $\begin{array}{c}81.11 \\
(64.26)\end{array}$ & $\begin{array}{c}67.03 \\
(55.32)\end{array}$ \\
\hline $\mathbf{T}_{\mathbf{3}}$ & $\begin{array}{c}56.66 \\
(48.84)\end{array}$ & $\begin{array}{c}72.22 \\
(58.20)\end{array}$ & $\begin{array}{c}87.77 \\
(69.58)\end{array}$ & $\begin{array}{c}72.22 \\
(58.87)\end{array}$ \\
\hline $\mathbf{T}_{4}$ & $\begin{array}{c}58.89 \\
(50.12)\end{array}$ & $\begin{array}{c}74.44 \\
(59.64)\end{array}$ & $\begin{array}{c}88.89 \\
(70.57)\end{array}$ & $\begin{array}{c}74.07 \\
(60.11)\end{array}$ \\
\hline $\mathbf{T}_{5}$ & $\begin{array}{c}55.55 \\
(48.19)\end{array}$ & $\begin{array}{c}72.22 \\
(59.64)\end{array}$ & $\begin{array}{c}82.22 \\
(65.08)\end{array}$ & $\begin{array}{c}70.00 \\
(57.16)\end{array}$ \\
\hline MEAN & $\begin{array}{c}54.44 \\
(47.56)\end{array}$ & $\begin{array}{c}70.44 \\
(57.11)\end{array}$ & $\begin{array}{l}83.55 \\
(66.28)\end{array}$ & \\
\hline $\mathrm{CD}(0.05)$ & \multicolumn{3}{|l|}{ Treatment $(\mathrm{T})$} & 1.29 \\
\hline & \multicolumn{3}{|l|}{ Category (L) } & 1.00 \\
\hline & \multicolumn{3}{|l|}{ TxL } & 2.24 \\
\hline
\end{tabular}


Table.4 Effect of seed size and pre-sowing treatments on germination energy (\%) of Sapindus mukorossi under laboratory condition

\begin{tabular}{|c|c|c|c|c|}
\hline $\begin{array}{l}\text { Category } \\
\text { Treatments }\end{array}$ & $\mathbf{L}_{1}$ & $\mathbf{L}_{2}$ & $\mathbf{L}_{3}$ & Mean \\
\hline $\mathrm{T}_{1}$ & $\begin{array}{c}20.00 \\
(26.55)\end{array}$ & $\begin{array}{c}31.11 \\
(33.88)\end{array}$ & $\begin{array}{c}41.11 \\
(39.86)\end{array}$ & $\begin{array}{r}30.74 \\
(33.43)\end{array}$ \\
\hline $\mathbf{T}_{2}$ & $\begin{array}{l}22.22 \\
(28.1)\end{array}$ & $\begin{array}{c}32.22 \\
(34.56)\end{array}$ & $\begin{array}{c}42.22 \\
(40.51)\end{array}$ & $\begin{array}{c}32.22 \\
(34.39)\end{array}$ \\
\hline $\mathbf{T}_{3}$ & $\begin{array}{c}28.89 \\
(32.49)\end{array}$ & $\begin{array}{c}38.89 \\
(38.56)\end{array}$ & $\begin{array}{c}52.22 \\
(46.25)\end{array}$ & $\begin{array}{l}40.00 \\
(39.1)\end{array}$ \\
\hline $\mathbf{T}_{4}$ & $\begin{array}{l}30.00 \\
(33.2)\end{array}$ & $\begin{array}{r}40.00 \\
(39.22)\end{array}$ & $\begin{array}{c}54.44 \\
(47.53)\end{array}$ & $\begin{array}{l}41.48 \\
(39.98)\end{array}$ \\
\hline$T_{5}$ & $\begin{array}{c}25.55 \\
(30.34)\end{array}$ & $\begin{array}{c}35.55 \\
(36.58)\end{array}$ & $\begin{array}{c}45.55 \\
(42.43)\end{array}$ & $\begin{array}{c}35.55 \\
(36.45)\end{array}$ \\
\hline Mean & $\begin{array}{c}25.33 \\
(30.14)\end{array}$ & $\begin{array}{l}35.55 \\
(36.56)\end{array}$ & $\begin{array}{c}47.11 \\
(43.32)\end{array}$ & \\
\hline \multirow[t]{3}{*}{$\mathrm{CD}(0.05)$} & \multicolumn{3}{|c|}{ Treatment(T) } & 1.00 \\
\hline & \multicolumn{3}{|c|}{ Category $(\mathrm{L})$} & 0.77 \\
\hline & \multicolumn{3}{|c|}{$\mathrm{T} \times \mathrm{L}$} & 1.72 \\
\hline
\end{tabular}

Note -Figures in the parentheses are arc- sine transformed values

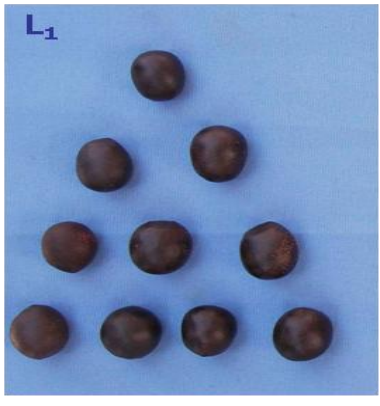

Small Size $(<1.2 \mathrm{~cm})$

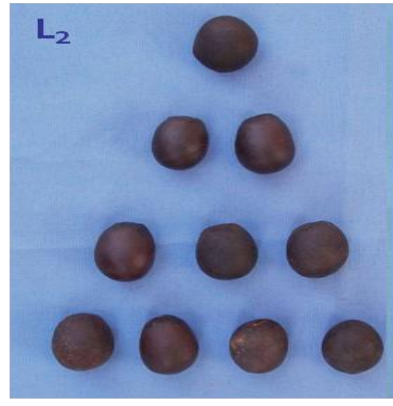

Medium Size

$(1.22-1.4 \mathrm{~cm})$

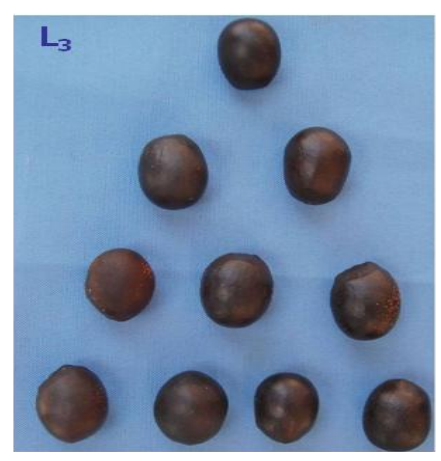

Large Size

$(>1.4 \mathrm{~cm})$

Fig. 1. Different seed size categories of Sapindus mukorossi 


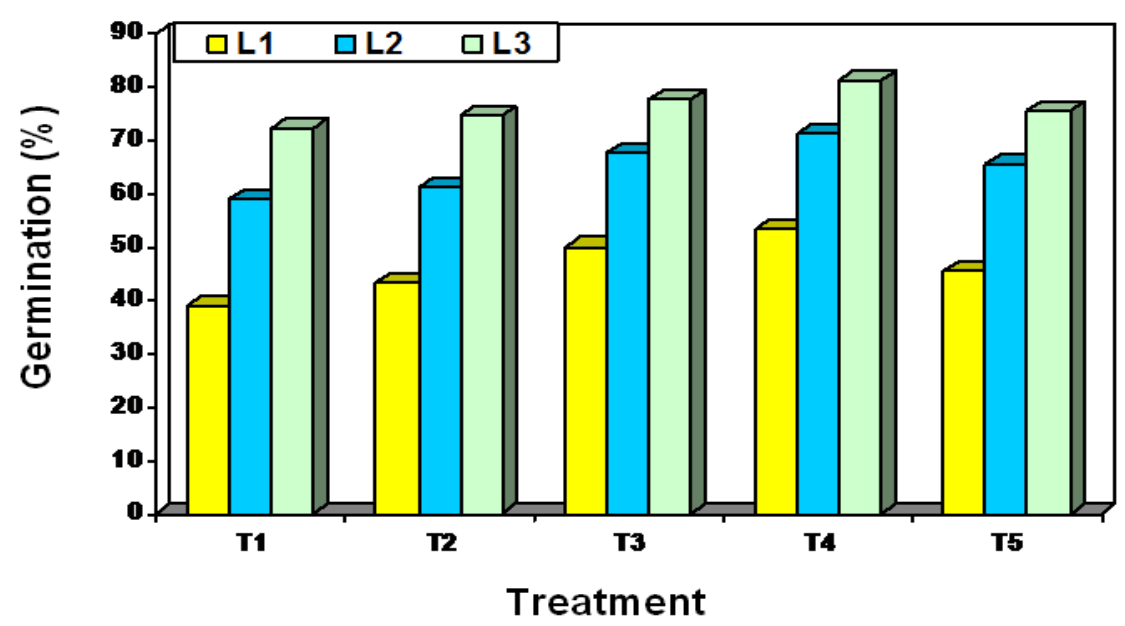

Fig. 2. Effect of seed size $x$ pre-sowing treatment interactions on germination $(\%)$ under laboratory condition

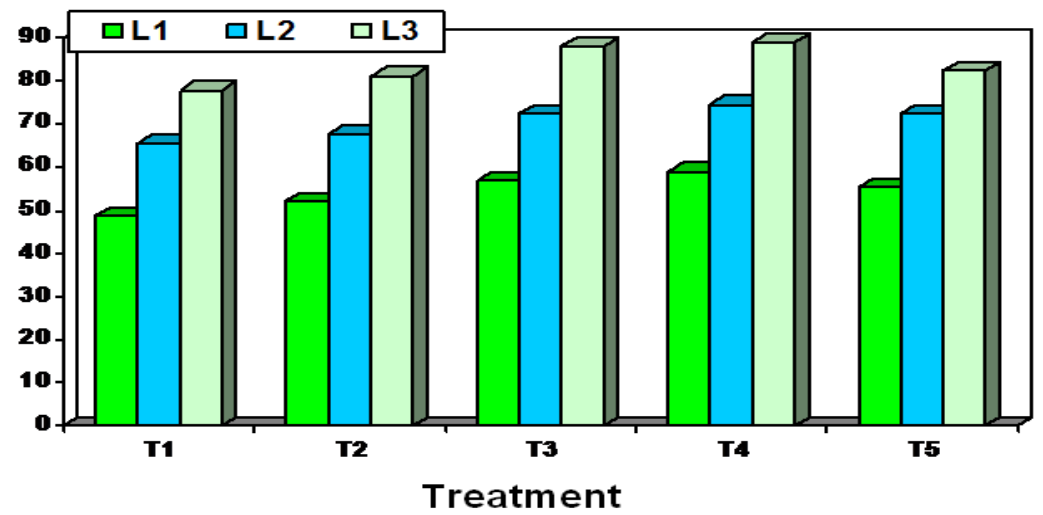

Fig. 3. Effect of seed size $x$ pre-sowing treatment interactions on germination capacity $(\%)$ under laboratory condition

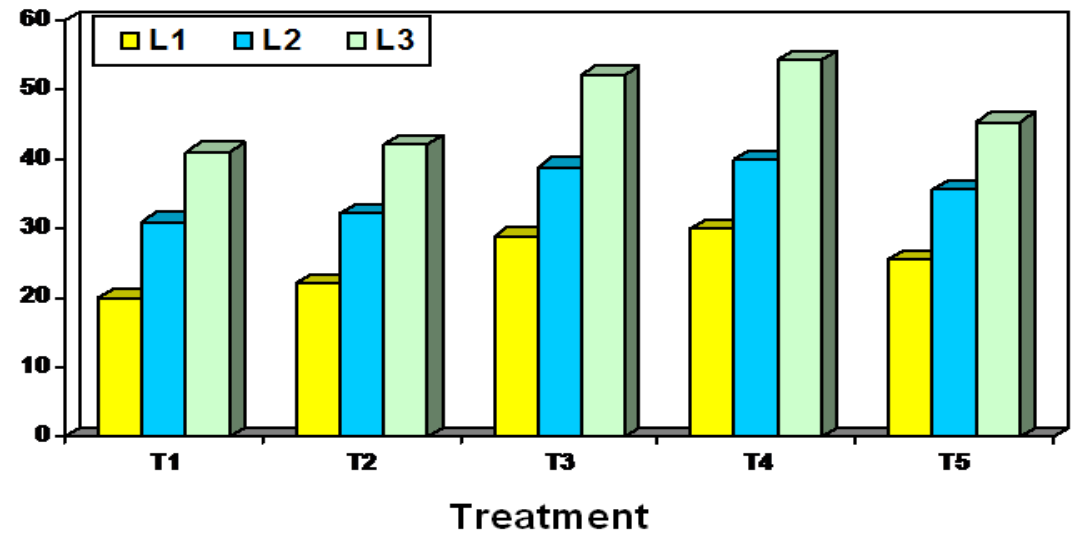

Fig. 4. Effect of seed size $x$ pre-sowing treatment interactions on germination energy under laboratory condition 
Germination per cent varied significantly among seed size categories and pre-sowing treatments. The maximum germination was recorded for $\mathrm{L}_{3}(76.22 \%)$ and $\mathrm{T}_{4}(68.52 \%)$ while minimum germination was recorded in $\mathrm{L}_{1}(46.22 \%)$ and $\mathrm{T}_{1}(56.66 \%)$ (Fig. 2). Seed size has affected the seed germination significantly (Baldwin, 1942). Generally large seed germinate faster and more completely than smaller ones due to more endosperm nutrient pool. Hence variation in germination may be due to the significant differences observed in seed dimensions and weight. In general, it was recorded that germination per cent increased with the size and weight of seed.

The variation among the seeds size categories with respect to germination per cent have been earlier reported in Sapindus emerginatus (Venkatesh and Nagarajaiah, 2010; Suresha et al., 2007), Jatropha curcas (Singh and Saxena, 2009), Acacia nilotica (Shaukat et al., 1999) and Acacia catechu (Khera et al., 2004), Salvadora persica and Jatropha curcas (Dagar et al., 2004), Syzygium cumini (Ponnammal et al., 1992), Terminalia bellerica and Acer oblongum (Negi and Todaria, 1997), Pongamia pinnata (Arjunan et al., 1994), and Leucaena leucocephala (Sharma and Sood, 1990).

The seeds of Sapindus mukorossi derived from the same lot responded differently to the different pre-sowing treatments under laboratory conditions. This may partly be explained on account of favourable condition in the germinator. Out of the five pre-sowing treatments studied, concentrated $\mathrm{H}_{2} \mathrm{SO}_{4}$ for 20 minutes followed by rinsing under running tap water $\left(\mathrm{T}_{4}\right)$ resulted in to higher germination. The concentrated $\mathrm{H}_{2} \mathrm{SO}_{4}$ soften the seed coat causing uniform inflow of water and unrestricted expansion of embryo. Increased germination have also been reported in Albizia lebbek and Cassia siamea
(Agboola et al., 2005), Quercus leucotrichophora (Gautam and Bhardwaj, 2001), Acacia nilotica (Khera and Saxena, 2003), Leucaena leucocephala (Puri et al., 2001), Cassia siamea (Kobmoo and Hellum, 1984), Quercus leucotrichophora (Chauhan and Verma, 1994), Acacia catechu (Jerlin and Vadivelu, 1994), Leucaena leucocephala var.K8 (Sharma and Sood, 1990), Albizia richardiana (Roy and Pathak, 1983) and Cassia fistula (Nalwadi et al., 1975). The interaction between seed size and pre-sowing treatment, recorded the maximum germination per cent in large sized seeds $\left(\mathrm{L}_{3}\right)$ when treated with conc. $\mathrm{H}_{2} \mathrm{SO}_{4}$ for 20 minutes, similar observations were obtained in Albizia lebbek (Mutha et al., 2004) and Albizia richardiana (Roy and Pathak, 1983).

Germination capacity also differs significantly due to seed size categories and pre-sowing treatments. The highest germination capacity was recorded in $\mathrm{L}_{3}$ $(83.55 \%)$ and $\mathrm{T}_{4}(74.07 \%)$ while minimum in $\mathrm{L}_{1}(54.44 \%)$ and $\mathrm{T}_{1}(64.07 \%)$ (Fig. 3). The results are in harmony with the findings in Eucalyptus globulus (Humara et al., 2002) and Eucalyptus citriodora (Aguiar and Nakane, 1983).

Germination energy also differs significantly due to pre-sowing treatments and seeds size categories (Fig. 4). Highest germination energy was recorded in $\mathrm{T}_{4}(41.48 \%)$ and $\mathrm{L}_{3}$ $(47.11 \%)$ while minimum in $\mathrm{L}_{1}(30.14 \%)$ and $\mathrm{T}_{1} \quad(30.74 \%)$. Large size seed varied significantly with respect to germination energy. The results are in harmony with the findings reported in Jatropha curcas (Singh and Saxena, 2009), Albizia lebbek (Kumar et al., 2001), Acacia senegal (Harsh et al., 2004) and Eucalyptus citriodora (Aguiar and Nakane, 1983). However, the effect of presowing treatments also varied significantly with reference to germination energy. The results are in harmony with those reported in 
Ribes orientale (Sharma et al., 2005), Acacia auriculiformis (Marunda, 1990), Indigofera pseudotinctoria (Jinnui et al., 2008), Grewia optiva (Singh et al., 1997) and Terminalia bellerica (Chakraborty et al., 1992).

Seed size is an important characteristic of seed quality as seed size has been shown to affect germination per cent, germination energy, and germination capacity, emergence rate, seed vigour, success of establishment, and growth. The seed size and pre sowing treatments often controls the germination and initial seedling growth. In seed size category, large seeds size gave maximum germinability parameters than the small seeds. Among persowing treatments, the highest germination per cent, germination capacity and germination energy was observed in concentrated $\mathrm{H}_{2} \mathrm{SO}_{4}$ for 20 minutes followed by rinsing under running tap water followed by cow dung treatment for 7 days. Pre-sowing treatment methods are employed for overcoming seed dormancy and used not only to ensure the rapid germination but it also decreases labour, cost and time for nursery production.

\section{Acknowledgement}

We thank the Department of Silviculture and Agroforestry of Dr YS Parmar University of Horticulture and Forestry, Nauni, Solan for providing necessary facilities.

\section{References}

Agboola, D. A., Ebofin, A. O., Aduradola, A. M. and Ajiboye, A. A. 2005. Effect of pre-sowing treatments on the germination of seeds of two savannah tree legumes. Indian Forester, 131 (5): 701-710.

Aguiar, I. B., and Nakane, J. T. 1983. Seed size of Eucalyptus citriodora: influence on germination and vigour. Brasil
Florestal, 13 (53): 25-28.

Athaya, C. D., 1985. Ecological studied of some forest tree seed I. seed morphology. Indian Journal of Forestry, 8 (1): 33-36.

Bahar, N., and Singh, V. R. R. 2007. Seed source selection of Sapindus mukorossi in Himachal Pradesh. Indian Forester, 133 (6): 731-736.

Bhardwaj, S. D., and Chakraborty, A. K. 1994. Studies on time of a seed collection, sowing and presowing treatments of Terminalia bellirica Roxb. And Terminalia chebula Retz. Indian Forester, 120 (5): 430-439.

Bonner, F. T., 1974. Seed testing. In: seeds of woody plants in The United States. Forest services, USDA, Washington DC, 136-152.

Catalan, L. A., and Macchiavelli, R. E. 1991. Improving germination in Prosopis flexuosa D.C. and Prosopis alba Griseb. With hot water treatments and scarification. Seed Science and technology, 19: 253-262.

Chakraborty, A. K., Pandey, O. N. and Bhardwaj, S. D. 1992. Presowing treatment on seeds of Terminalia bellirica. Journal of Research, Birsa Agricultural University, 4 (1): 95-98

Dagar, J. C., Bhagwan, H. and Kumar, Y. 2004. Seed germination studies on Salvadora persica and Jatropha curcas. Indian Journal of Forestry, 27 (3): 283 289.

Gautam, J., and Bhardwaj, S. D. 2001. Effect of seed size and pre-sowing treatments on germination of ban oak (Quercus leucotrichophora). Indian Journal of Forestry, 24 (3): 311-315.

Gurunathan, N., Srimathi, P. and Paramathma, M. 2009. Influence of size polymorphism on seed and seedling quality of Jatropha curcas. Madras Agricultural Journal, 96 (1/6): 62-66.

Harsh, L. N., Bohra, M. D., Khan, H. A. and 
Tewari, J. C. 2004. Effect of drought on seed quality and germination of Acacia senegal Willd. Indian Journal of Forestry, 27 (2): 181-185.

Humara, J. M., Casares, A., Majada, J. 2002. Effect of seed size and growing media water availability on early seedling growth in Eucalyptus globulus. Forest Ecology and Management, 167 (1/3): 111.

I S T A, 1966. International rules for seed testing. Proceedings for International Seed Testing association, 31: 1-152.

Jinnui, Y., Lixing, H., Minge, B., Hua, Q. and Tanjun, Z. 2008. Effect of different treatments on seed germination of Indigofera pseudotinctoria. Journal of Zhejiang Forestry Science and Technology, 25 (5): 57-60.

Khasa, P. D., 1992. Scarification of limba seeds with hot water, bleach and acid. Tree planters note, 43 (4): 150-152.

Khera, N., and Saxena, A. K. 2003. Effect of pre-sowing treatments on seed germination and seedling growth of Acacia nilotica willd. Range Management and Agroforestry, 24 (2): 104-113.

Khera, N., Saxena, A. K. and Singh, R. P. 2004. Seed size variability and its influence on germination and seedling growth of five multipurpose tree species. Seed Science and Technology, 32 (2): 319-330.

Kobmoo, B., and Hellum, A. K. 1984. Hot water and acid improve their germination of Cassia siamea Britt. Seeds. Embryani, 1: 27-33.

Kumar, M., Bhardwaj, S. D. and Panwar, P. 2001. Effect of pod and seed size on germination parameters of Albizia lebbek. Indian Journal of Forestry, 24 (4): 496-499.

Manonmani, V., Vanangamudi, K. and Rai, R. S. V. 1996. Effect of seed size on seed germination and vigour in
Pongamia pinnata. Journal of Tropical Forest Science, 9 (1): 1-5.

Marunda, C. T., 1990. Effects of seed pretreatments on the development of Acacia auriculiformis and Acacia holosericea seedlings. ACIAR Proceedings Series, 28: 33-36.

Mathur, R. S., Sharma, K. K. and Rawat, M. M. S. 1984. Germination behaviour of various provenances of Acacia nilotica species indica. Indian Forester, 110 (5): 435-499.

Mutha, N., Bohra, M. D., Burman, U. and Harsh, L. N. 2004. Effect of seed size and pretreatments on germination of Albizia lebbek (L.) Benth. Indian Journal of Forestry, 27 (1): 11-14.

Parameswari, K., and Srimathi, P. 2009.Seed size influencing seed quality in few tree crops. International Journal of Plant Sciences, 4 (1):208-211.

Puri, S., Agrawal, S., Patel, R. K. and Swamy, S. L. 2001. Germination and viability testing of some multipurpose trees used in agroforestry practices. Indian Journal of Agroforestry, 3(1): 69-79.

Roy, M. M., and Pathak, P. S. 1983. Seed polymorphism and germination in Albizia richardiana King \& Prain. My forest, 19 (2): 89-95.

Schmidt, L., 2000. Guide of handling of tropical and subtropical forest seeds. Danida Forest Seed Centre. Hunlobaeck, Denmark, p. 287.

Sharma, S., Kumar, S., Thakur K. S., Negi, P. S. 2005. Study on effect of pre-sowing treatments on germination of Ribes orientale Desf. Seeds. Indian Forester, 131 (5): 667-672.

Shaukat, S. S., Siddiqui, Z. S. and Seemi, A. 1999. Seed size variation and its effect on germination, growth and seedling survival in Acacia nilotica subsp.indica (Benth.) Brenan. Pakistan Journal of Botany, 31 (2): 253-263.

Singh, C., Kumar, V. and Sharma, N. K. 
1997. Germination behaviour of Grewia optiva (Drumm.) seeds under different pre-sowing treatments. Van Vigyan, 35 (3/4): 132-136.

Singh, N., and Saxena, A. K. 2009. Seed size variation and its effect on germination and seedling growth of Jatropha Curcas L. Indian Forester, 135 (8): 1135-1142.

Suresha, N. L., Balachandra, H. C. and Shivanna, H. 2007. Effect of seed size on germination, viability and seedling biomass in Sapindus emerginatus
(Linn). Karnataka Journal of Agricultural Sciences, 20 (2): 326-327.

Troup, R. S., 1921. Siliviculture of Indian trees. Vol (3). Nasik. Govt. of Indian Press, p. 240.

Venkatesh, L., and Nagarajaiah, C. 2010. Effect of seed size on germination, viability and seedling biomass in Sapindus emerginatus Linn. Environment and Ecology, 28 (1): 2527.

\section{How to cite this article:}

Varun Attri, K.S. Pant, Navjot Singh and Vipasha Negi. 2017. Influence of Seed Size and PreSowing Treatments on Germination Parameters of Sapindus mukorossi Gaertn under Laboratory Condition. Int.J.Curr.Microbiol.App.Sci. 6(10): 2788-2799. doi: https://doi.org/10.20546/ijcmas.2017.610.327 